\title{
Modulatory effect of laser irradiation on mastoparan-7-induced contraction
}

\author{
ELŻBIETA GRZEŚK ${ }^{1}$, MAGDALENA MACKIEWICZ-MILEWSKA ${ }^{2}$, HANNA MACKIEWICZ-NARTOWICZ ${ }^{3}$, \\ MICHAŁ WICIŃSKI ${ }^{4}$, IGOR BURDZIŃSKI ${ }^{5}$, MARYIA KORSAK $^{5}$, ANNA KOPCZYNSSKA ${ }^{5}$, \\ WOJCIECH HAGNER ${ }^{2}$ and GRZEGORZ GRZEŚSK ${ }^{5}$ \\ ${ }^{1}$ Department of Pediatrics, Hematology and Oncology, Faculty of Medicine; Departments of ${ }^{2}$ Rehabilitation \\ and ${ }^{3}$ Phoniatry and Audiology, Faculty of Health Sciences; ${ }^{4}$ Department of Pharmacology and Therapeutics, \\ Faculty of Medicine; ${ }^{5}$ Second Department of Cardiology, Division of Clinical Pharmacology, Faculty of \\ Health Sciences, Collegium Medicum, Nicolaus Copernicus University, 85-094 Bydgoszcz, Poland
}

Received October 22, 2018; Accepted August 20, 2019

DOI: $10.3892 /$ br.2019.1255

\begin{abstract}
Mastoparan-7 activates guanine nucleotide-binding proteins (G-proteins) and stimulates both apoptosis and increases in cytoplasmic calcium concentration and may induce smooth muscle contraction. The primary aim of the present study was to evaluate the modulatory effect of laser stimulation on vascular smooth muscle contraction induced by direct stimulation of G-protein with mastoparan-7. Experiments were performed on isolated and perfused tail arteries of Wistar rats. Contraction force in the model was measured by increased levels of perfusion pressure with a constant flow. Irradiation treatment was applied directly to the blood vessels. The laser was applied in increasing doses of $10 \mathrm{~mW}(\mathrm{E}=1.8 \mathrm{~J}), 30 \mathrm{~mW}$ $(\mathrm{E}=5.5 \mathrm{~J})$ and $110 \mathrm{~mW}(\mathrm{E}=19.8 \mathrm{~J})$. Time of exposure was $3 \mathrm{~min}$ for each irradiation. In the laser-stimulated arteries, a significant and dose-dependent decrease was observed. The half maximal effective concentration values were $4.43 \pm 2.2 \times 10^{-8}$, $2.4 \pm 0.56 \times 10^{-7}, 3.2 \pm 0.72 \times 10^{-7}$ and $7.7 \pm 0.3 \times 10^{-7} \mathrm{M} / 1$ in the control and 10, 30 and $110 \mathrm{~mW}$ laser irradiation groups, respectively. Significant $(\mathrm{P}<0.001)$ changes were identified for all laser treatment groups in comparison with the control. When analyzing the function of calcium ion $\left(\mathrm{Ca}^{2+}\right)$ stores was analyzed, a significant inhibition of influx from both intra- and extracellular $\mathrm{Ca}^{2+}$ stores was observed. The results from the
\end{abstract}

Correspondence to: Dr Elżbieta Grześk, Department of Pediatrics, Hematology and Oncology, Faculty of Medicine, Collegium Medicum, Nicolaus Copernicus University, Skłodowskiej-Curie 9, 85-094 Bydgoszcz, Poland

E-mail: ellag@cm.umk.pl

Abbreviations: $\mathrm{CRC}$, concentration response curve; $\mathrm{EC}_{50}$, half maximal effect concentration; $\mathrm{E}_{\max }$, maximal tissue response; mas-7, mastoparan-7; PLC, phospholipase C; LLLI, low-level laser irradiation

Key words: low-level laser irradiation, mastoparan-7, guanine nucleotide-binding protein, phospholipase $\mathrm{C}$ present study suggested that contraction induced by direct activation of G-protein with mastoparan-7 may by effectively inhibited by laser radiation, and that the effect was associated with an inhibition of $\mathrm{Ca}^{2+}$ influx from both intracellular and extracellular $\mathrm{Ca}^{2+}$ stores.

\section{Introduction}

Laser biostimulation with low and mid-level laser therapy has been used for a number of years as a well-known method of healing soft and hard tissues (1-8). In addition, the anti-inflammatory effects of this therapy have been described extensively $(2,6,9)$. Low-level laser irradiation (LLLI) is able to modify different biological pathways, including increases in mitochondrial respiration, and ATP synthesis proliferation of mesenchymal stem cells and cardiac stem cells $(10,11)$.

The potential mechanism of the effect of light on biological structures, in particular vascular smooth muscle, have been examined previously; experimental studies have suggested that lasers of power $<100 \mathrm{~mW}$ cause relaxation of smooth muscle of blood vessels (12-15). Two studies $(11,13)$ have demonstrated that LLLI may cause photorelaxation of blood vessels, including coronary arteries, and may prevent their restenosis following percutaneous transluminal coronary angioplasty $(11,16)$. A number of experimental studies analyzed the effect of LLLI on vascular smooth muscle cells following pretreatment with $\alpha$-adrenoceptors agonists (adrenalin and phenylephrine) and peptides, including vasopressin or endothelin-1 $(17,18)$. To the best of our knowledge, the effect of non-receptor stimulation has not been analyzed previously.

Mastoparan-7 is a basic tetradecapeptide isolated from wasp venom. The mechanism of its action is associated with the activation of guanine nucleotide-binding proteins (G-proteins). The peptide has been demonstrated to stimulate phospholipase C (PLC) in several cellular compartments such as rat mast cells, rat hepatocytes and human HL-60 leukemia cells. By contrast, inhibition of PLC by mastoparan has been demonstrated in SH-SY5Y human neuroblastoma cells and in human astrocytoma cells (19). In vascular smooth cells, it is able to increase contractility (20-22). 
Calcium ions $\left(\mathrm{Ca}^{2+}\right)$ serve a central role in general cell processes. According to pathological factors, $\mathrm{Ca}^{2+}$ concentration changes occur in various cell compartments, which may induce apoptosis (23-25). An increase in $\mathrm{Ca}^{2+}$ describes one of final elements of programmed cell death and physiological concentrations may differ significantly in cell compartments.

Our previous studies confirmed that mastoparan-7 is able to increase the calcium load in smooth muscle cytoplasm by activation of calcium influx from intra and extracellular calcium stores in an isolated resistant artery model $(20,21)$. In addition, during ischemia and reperfusion, the pathway associated with direct stimulation of $\mathrm{G}$-proteins remains active (22).

The primary aim of the present study was to evaluate the modulatory effect of low and moderate laser irradiation on vascular smooth muscle contraction induced by direct stimulation of G-proteins with mastoparan-7.

\section{Materials and methods}

Animals. Experiments were performed on isolated and perfused tail arteries of Wistar rats (10 males; age, 8 weeks; body weight, 250-270 g; Hodowla Zwierząt Laboratoryjnych). Animals were housed at $20-21^{\circ} \mathrm{C}$ with a humidity of $50-60 \%$ and 12-h light/dark cycles and had ad libitum access to food and water. Prior to tail artery isolation, rats were anesthetized by intraperitoneal injection of $1,200 \mathrm{mg} / \mathrm{kg}$ urethane and euthanized by cervical dislocation. The study protocol was approved by the Local Ethics Committee for Experiments on Animals, (Bydgoszcz, Poland). All studies were performed in accordance with the United States of America National Institutes of Health guidelines (26).

Drugs and solutions. Mastoparan-7 (G-protein activator), mastoparan-17 (negative control), and $\mathrm{Krebs}$ solution containing $\mathrm{NaCl}(71.8 \mathrm{mM} / \mathrm{l}), \mathrm{KCl}(4.7 \mathrm{mM} / \mathrm{l}), \mathrm{CaCl}_{2}(1.7 \mathrm{mM} / \mathrm{l}) \mathrm{NaHCO}_{3}$ (28.4 mM/l), $\mathrm{MgSO}_{4}(2.4 \mathrm{mM} / \mathrm{l}), \mathrm{KH}_{2} \mathrm{PO}_{4}(1.2 \mathrm{mM} / \mathrm{l})$ and glucose $(11.1 \mathrm{mM} / \mathrm{l})$ were purchased from Sigma Aldrich; Merck KGaA.

Study design and conduction. Following dissection from the surrounding tissues, 2-3-cm long segments of rat tail arteries were cannulated and connected to a perfusion device. The distal part was held in place with $500 \mathrm{mg}$ weight and the tail was placed in a $20 \mathrm{ml}$ container filled with oxygenated Krebs solution at $37^{\circ} \mathrm{C}(\mathrm{pH} 7.4)$. The perfusion pressure was continuously measured. Perfusion solution flow was gradually increased using a peristaltic pump to $1 \mathrm{ml} / \mathrm{min}$, until the optimum perfusion pressure of 2-4 $\mathrm{kPa}$ was reached (25). The study utilized a semiconductor laser $(400 \mathrm{~mW}$, wavelength $=810 \mathrm{~nm}$ ), operating in continuous-wave mode. Subsequent to achieving maximal vasospasm, the arteries were rinsed and stabilized for a period of $30 \mathrm{~min}$ prior to exposure to laser irradiation. The arteries were placed on a plate and the laser header was positioned on a tripod $\sim 1 \mathrm{~cm}$ from the irradiated tissue. The irradiation was applied directly on the blood vessels without utilization of a glass chamber. The laser was applied in increasing doses of $10 \mathrm{~mW}$ ('L1'; E=1.8 J), $30 \mathrm{~mW}$ ('L2'; E=5.5 J), $110 \mathrm{~mW}$ ('L3'; E=19.8 J). Time of exposition was $3 \mathrm{~min}$ for each irradiation (17). In experiments performed on endothelium-denudated arteries, the endothelium was removed with the compressed air (temperature $=37^{\circ} \mathrm{C}$, pressure $=1.0-1.1 \mathrm{~atm}$ ). The absence of endothelium was confirmed with an acetylcholine test (single dose of acetylcholine $10^{-5}$ $\mathrm{M} / \mathrm{l})$. To evaluate constriction associated with the intracellular calcium, experiments were performed in calcium-free Krebs solution (phase 1) and after switching to the Krebs solution analysis of constriction related to calcium influx from extracellular space was performed (phase 2).

Data analysis and statistical procedures. Investigations were performed using a TSZ-04 system (Experimetria Kft.). Perfusion pressure was measured on BPR-01 and BPR-02 (Experimetria Kft.) devices, and vascular smooth muscle tension was measured using an FSG-01 transducer connected with a Graphtec GL820 midi LOGGER digital recorder (Graphtec Corporation). All transducers used in the experiments were produced by Experimetria Kft. Concentration-response curves (CRCs) were calculated according to the van Rossum method (27). Maximum response of tissue ( $\left.E_{\max }\right)$ was calculated as a proportion of the maximal response for phenylephrine. The half maximal effective concentration $\left(\mathrm{EC}_{50}\right)$ was estimated using classical pharmacologic methods with the $\mathrm{pD}_{2}$ value, the negative logarithm of the $\mathrm{EC}_{50}$. The $\mathrm{CRC}$ and $\mathrm{E}_{\max }$ values were used in all calculations estimating the statistical significance. Mastoparan-17 was included in all experiments as the negative control.

Results are presented as mean \pm standard deviation. Tukey's Honest Significant Difference test was used following two-way analysis of variance for multiple comparisons of means. $\mathrm{P}<0.05$ was considered to indicate a statistically significant difference. Statistical analysis was performed using STATISTICA 12.5 (StatSoft, Inc.).

\section{Results}

Concentration-response curve obtained for mastoparan-7 presents a sigmoidal association. In the laser-irradiated arteries, a significant rightward shift with significant decrease in maximal responses was observed. This effect was dependent on the power of laser irradiation (Fig. 1). For all samples in which the effect was measured as $\geq 20 \%$, the difference was deemed statistically significant. The $\mathrm{EC}_{50}$ values were $4.43 \pm 2.2 \times 10^{-8}, 2.4 \pm 0.56 \times 10^{-7}, 3.2 \pm 0.72 \times 10^{-7}$ and $7.7 \pm 0.3 \times 10^{-7}$ $\mathrm{M} / 1$ in the control and 10, 30 and $110 \mathrm{~mW}$ laser irradiation groups, respectively. Significant $(\mathrm{P}<0.001)$ changes were observed for all laser power groups in comparison with the control.

In experiments performed on the endothelium-denudated arteries, the $\mathrm{EC}_{50}$ values were $2.25 \pm 2.5 \times 10^{-9}, 2.73 \pm 1.9 \times 10^{-9}$, $2.63 \pm 2.1 \times 10^{-9}$ and $2.15 \pm 1.8 \times 10^{-9} \mathrm{M} / 1$ in the control and 10 , 30 and $110 \mathrm{~mW}$ laser irradiation groups, respectively. Values did not differ significantly. All $\mathrm{E}_{\max }, \mathrm{EC}_{50}$ and $\mathrm{pD}_{2}$ values are presented in Table I. Changes in trends in $\mathrm{pD}_{2}$ values are presented in Fig. 2.

When analyzing the changes in perfusion pressure as a result of intracellular $\mathrm{Ca}^{2+}$ influx during mastoparan-7-induced contraction in the control group, a significant increase was observed in comparison with the negative control, mastoparan-17 $(\mathrm{P}<0.001)$. Following laser irradiation at 10, 30 and $110 \mathrm{~mW}$, a significant decrease in vascular reaction 


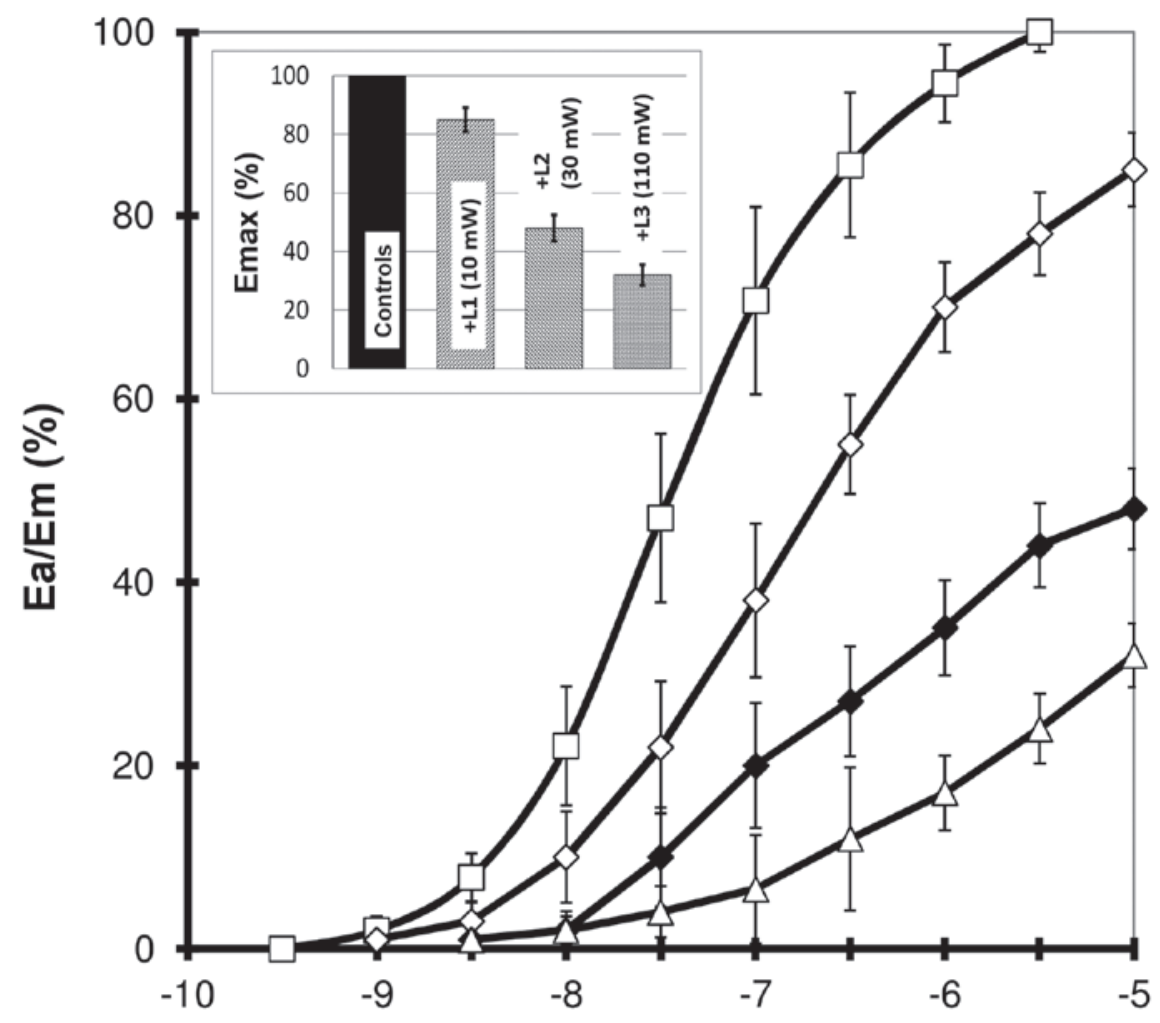

Log of molar concentration of mastoparan-7

$-\square$-Controls $(n=18)$

$\leftrightarrow+\mathrm{L} 2(30 \mathrm{~mW})(\mathrm{n}=12)$
$\curvearrowright+L 1(10 \mathrm{~mW})(\mathrm{n}=15)$

$\neg-+\mathrm{L} 3(110 \mathrm{~mW})(\mathrm{n}=12)$

Figure 1. Concentration response curves and $\mathrm{E}_{\max }$ values for mastoparan-7 in the control and in laser-irradiated arteries (10, 30 and $\left.110 \mathrm{~mW}\right) . \mathrm{E}_{\max }$, maximum response of tissue.

was observed following influx of extracellular $\mathrm{Ca}^{2+}$ into the cytoplasm, whereas in intracellular $\mathrm{Ca}^{2+}$, a significant decrease was only identified at 30 and $110 \mathrm{~mW}$ (Table II; Fig. 3). No additional benefit in increasing the laser power from 30 to $110 \mathrm{~mW}$ was observed.

\section{Discussion}

Arterial smooth muscle function has been investigated in a number of different studies, involving typical pharmacological stimulation with the use of receptor agonists including $\alpha_{1}$-adrenoceptors, vasopressin type 1 receptors or the L-type calcium channel $(20-25,28,29)$. Direct stimulation of G-proteins with mastoparan-7 was described in certain studies $(20-22,29,30)$. The present study investigated the possibility of the induction of photorelaxation in laser-pretreated arteries. Results from our previous studies confirmed the occurrence of photorelaxation in arteries stimulated with receptor agonists $(17,18,29,30)$. Constriction of vascular smooth muscle cells in the presence of mastoparan-7 was demonstrated by Kanagy and Webb (29), and Birnbaumer (30) described experiments on spiral cutting fragments of the common carotid artery.
In the present study, laser irradiation significantly inhibited mastoparan-7-induced constriction of vascular smooth muscle cells. In addition, proportional to the laser power, a decrease in perfusion pressure caused by intra- and extracellular $\mathrm{Ca}^{2+}$ influx inhibition was observed. Mastoparan-7 leads to degranulation of mast cells by activation of phospholipase $\mathrm{A}_{2}$ at a concentration of $5 \times 10^{-5} \mathrm{M} / 1$ (31).

Previous studies performed on vessels suggested that laser photorelaxation in vessels stimulated pharmacologically is partially endothelium-dependent process $(17,18)$, therefore degradation of the vascular endothelium may able to eliminate the inhibitory effect of laser irradiation on vessels reactivity. In the experiments performed in the present study, removal of the vascular endothelium prevented the inhibitory effect of laser irradiation on vessel walls stimulated by G-protein with mastoparan-7; consequently, we concluded that laser vasodilation in mastoparan-7-induced arteries may be an endothelium-dependent process. Similar effects were observed for endothelin-1 and phenylephrine stimulation of entothelin-1 and $\alpha_{1}$-adrenoceptors, respectively (17).

Similar effects of LLLI-induced vasorelaxation were described by Gal et al (12) and Steg et al (13). Results of their 
Table I. EC50, maximal response and relative potency for mastoparan-7 in controls and in the 10, 30 and $110 \mathrm{~mW}$ laser irradiation groups for normal and endothelium-denudated arteries.

A, Normal vessels

\begin{tabular}{|c|c|c|c|c|c|c|}
\hline Groups & $\mathrm{N}^{\mathrm{a}}$ & $\% \mathrm{E}_{\max }^{\mathrm{b}}$ & $\mathrm{EC}_{50}(\mathrm{M} / \mathrm{l})$ & $\mathrm{pD}_{2}$ & $\mathrm{RP}^{\mathrm{c}}$ & $\mathrm{P}$-value \\
\hline Control & 18 & 100 & $4.43 \pm 2.2 \times 10^{-8}$ & $7.35 \pm 0.21$ & 1.000 & - \\
\hline \multicolumn{7}{|c|}{ Laser treatment, $\mathrm{mW}$} \\
\hline +L1 (10) & 15 & $85 \pm 8$ & $2.4 \pm 0.56 \times 10^{-7}$ & $6.62 \pm 0.13$ & 0.185 & $<0.0001$ \\
\hline +L2 (30) & 12 & $48 \pm 8$ & $3.2 \pm 0.72 \times 10^{-7}$ & $6.49 \pm 0.09$ & 0.138 & $<0.0001$ \\
\hline +L3 (110) & 12 & $32 \pm 7$ & $7.7 \pm 0.3 \times 10^{-7}$ & $6.11 \pm 0.20$ & 0.058 & $<0.0001$ \\
\hline
\end{tabular}

B, Endothelium-denudated artery

\begin{tabular}{|c|c|c|c|c|c|c|}
\hline Groups & $\mathrm{N}^{\mathrm{a}}$ & $\% \mathrm{E}_{\max }^{\mathrm{b}}$ & $\mathrm{EC}_{50}(\mathrm{M} / \mathrm{l})$ & $\mathrm{pD}_{2}$ & $\mathrm{RP}^{\mathrm{c}}$ & P-value \\
\hline Control & 18 & 100 & $2.25 \pm 2.5 \times 10^{-9}$ & $8.65 \pm 0.24$ & 1.000 & - \\
\hline \multicolumn{7}{|c|}{ Laser treatment, $\mathrm{mW}$} \\
\hline +L1 (10) & 15 & $85 \pm 8$ & $2.73 \pm 1.9 \times 10^{-9}$ & $8.56 \pm 0.21$ & 1.213 & ns \\
\hline$+\mathrm{L} 2(30)$ & 12 & $48 \pm 8$ & $2.63 \pm 2.1 \times 10^{-9}$ & $8.58 \pm 0.09$ & 1.169 & ns \\
\hline +L3 (110) & 12 & $32 \pm 7$ & $2.15 \pm 1.8 \times 10^{-9}$ & $8.67 \pm 0.20$ & 0.956 & ns \\
\hline
\end{tabular}

${ }^{a}$ Number of concentration-response curves used for calculations. ${ }^{b} \mathrm{E}_{\max }$, calculated as a percentage of maximal response for controls. ${ }^{\mathrm{c}} \mathrm{RP}$, calculated as $\mathrm{EC}_{50}$ for controls/ $\mathrm{EC}_{50}$. $\mathrm{E}_{\max }$, maximum response of tissue; $\mathrm{EC}_{50}$, half maximal effective concentration; $\mathrm{pD}_{2}$, negative logarithm of the $\mathrm{EC}_{50}$; RP, relative potency; ns, not significant.

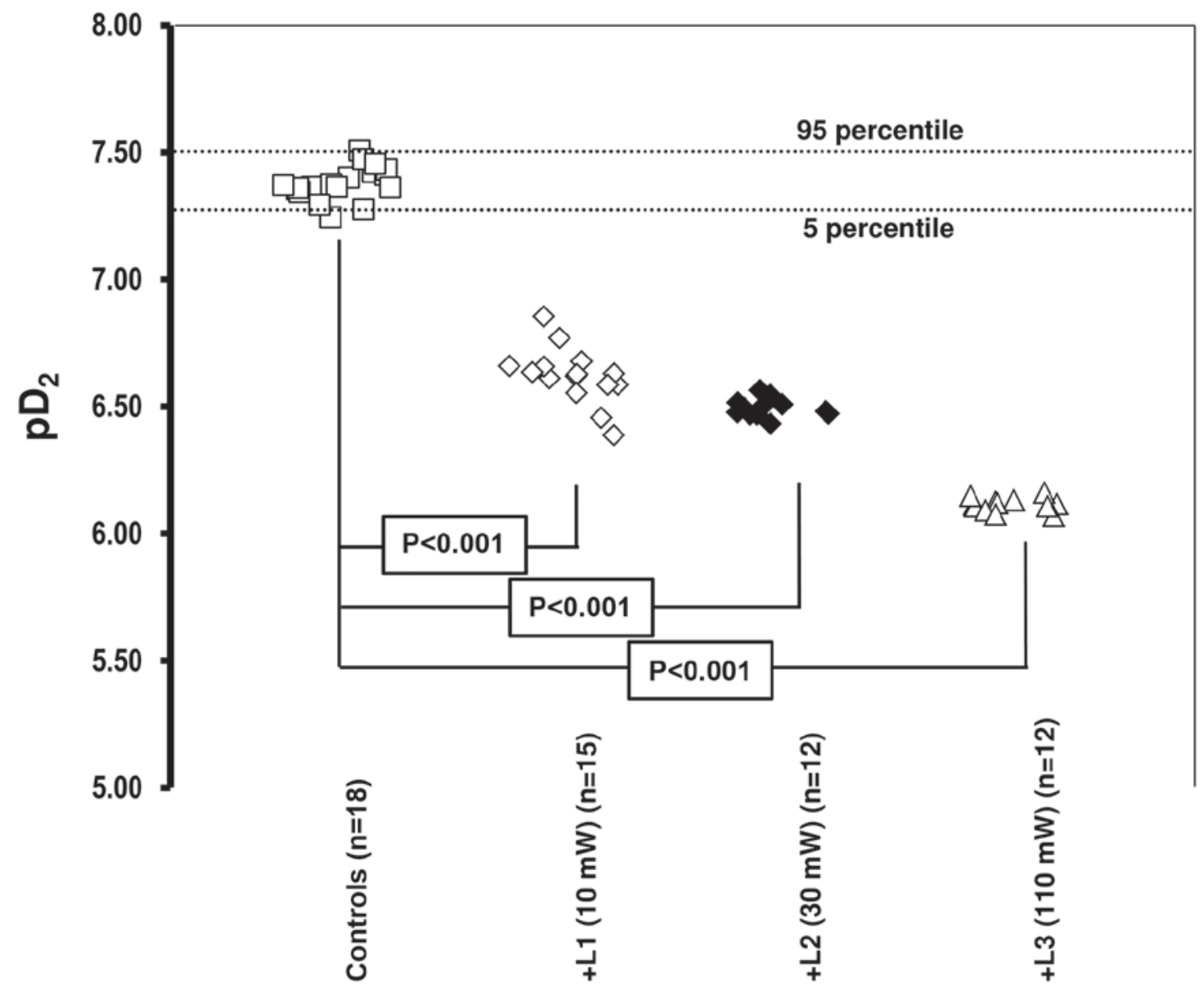

Figure 2. $\mathrm{pD}_{2}$ values for mastoparan-7 in the control and laser irradiated (10, 30 and $110 \mathrm{~mW}$ ) groups. 
Table II. Maximal perfusion pressure for mastoparan-7 induced contraction activated by $\mathrm{Ca}^{2+}$ influx from intracellular (phase 1) and extracellular $\mathrm{Ca}^{2+}$ stores (phase 2) in the control and laser irradiated (10, 30 and $110 \mathrm{~mW}$ ) groups.

Phase 1

Groups $\quad$ Perfusion pressure, $\mathrm{mmHg}$

Control 16

Laser treatment, $\mathrm{mW}$

+L1 (10)
+L2 (30)
+L3 (110)

Mastoparan-17
12

12

12

10
$19.1 \pm 3.2$

$15.2 \pm 1.7^{\mathrm{f}}$

$12.4 \pm 3.5^{\mathrm{a}, \mathrm{c}}$

$11.8 \pm 5.6^{\mathrm{a}, \mathrm{e}}$

$12.2 \pm 5.4^{\mathrm{a}}$
Phase 2

$\mathrm{n}$

Perfusion pressure, $\mathrm{mmHg}$

${ }^{\mathrm{a}} \mathrm{P}<0.05$ and ${ }^{\mathrm{b}} \mathrm{P}<0.001 \mathrm{vs}$. control; ${ }^{\mathrm{C}} \mathrm{P}<0.05 \mathrm{vs} . \mathrm{L} 1 ;{ }^{\mathrm{d}} \mathrm{P}<0.0001 \mathrm{vs} . \mathrm{L} 1 ;{ }^{\mathrm{e}} \mathrm{P}=0.06$ vs. $\mathrm{L} 1 ;{ }^{\mathrm{f}} \mathrm{P}=0.07 \mathrm{vs}$. control. Data are presented as the mean \pm standard deviation.
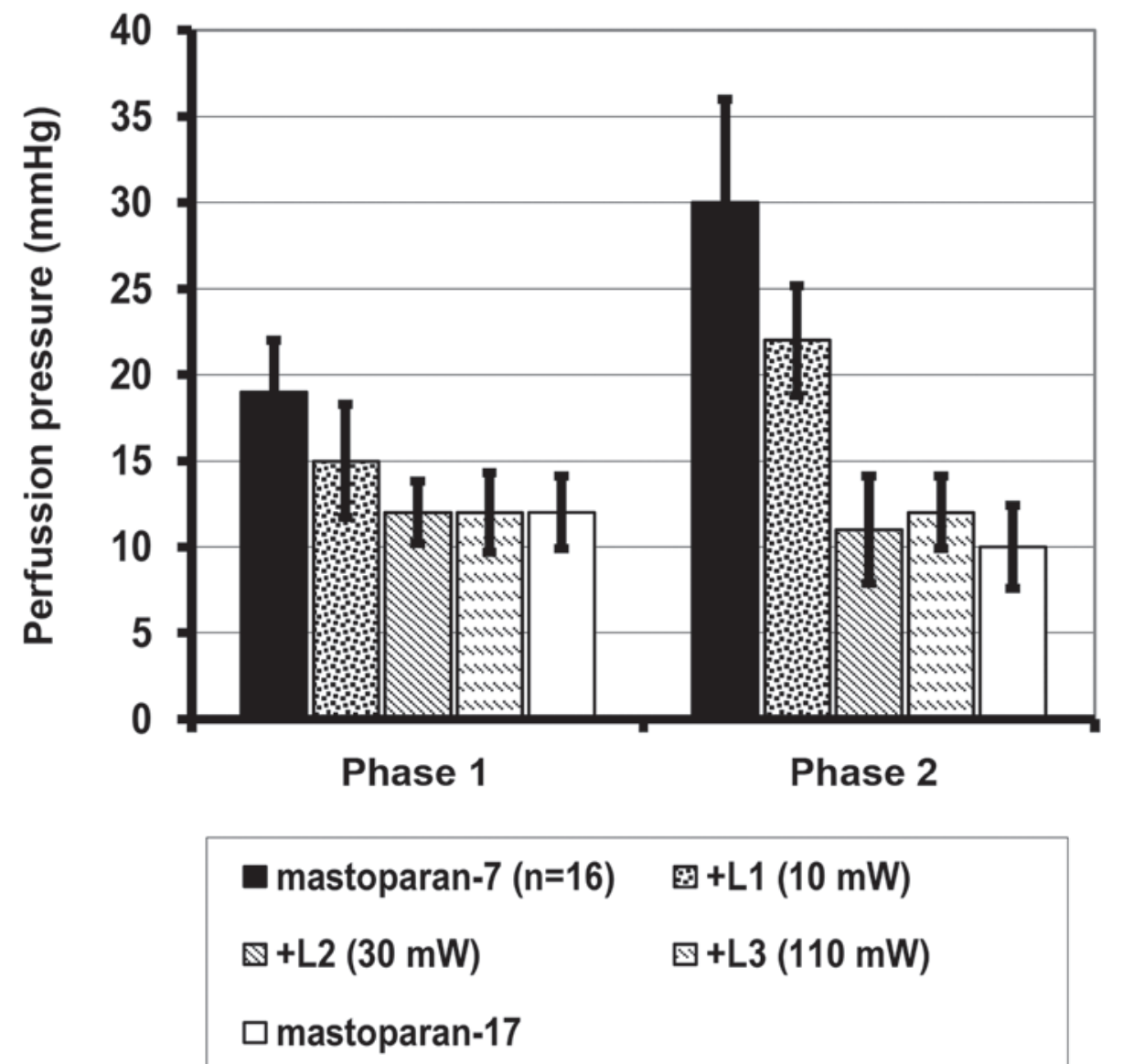

Figure 3. Effect of guanine nucleotide-binding protein activation by mastoparan 7 on perfusion pressure, accompanied by changes in intra- and extracellular $\mathrm{Ca}^{2+}$ levels in comparison with the negative control (mastoparan-17) and in laser irradiated arteries (10, 30 and $\left.110 \mathrm{~mW}\right)$.

studies indicated that laser irradiation at a power $<100 \mathrm{~mW}$ was responsible for constant smooth muscle relaxation, whereas continuous wave laser at a power $<1 \mathrm{~W}$ induced vasoconstriction (14). By contrast, the opposite effect of endothelium removal was described by Gal et al (12) and Steg et al (13), who postulated that the vasodilatory effect of laser treatment was not endothelium-dependent. These studies were able to induce smooth muscle dilation in endothelium-denudated arteries using in vitro and in vivo experiments. In addition, Steg et al (13) observed relaxation of smooth muscles induced by low level pulse lasers, even if the muscles had not been previously contracted (13). Maegawa et al (32) also described vasodilation of arterioles in a study investigating the effect of LLLI smooth muscle reactivity. This study suggested that the observed effects were partially due to NO release from the vascular endothelium, particularly in the initial phase, whereas in the late phase LLLI induced a decrease of $\mathrm{Ca}^{2+}$ in microvascular smooth muscles. Generally, the process of LLLI-induced vasodilation appears to 
be a result of processes occurring in the large and small vessels, pre-capillary sphincteromas and microcirculation.

In conclusion, the results of the present study suggest that contraction induced by direct activation of G-protein with mastoparan-7 may by effectively inhibited by laser irradiation, and may be an endothelium-dependent process. In addition, this effect was laser power-dependent, and associated with the inhibition of $\mathrm{Ca}^{2+}$ influx from both intra and extracellular calcium stores.

\section{Acknowledgements}

Not applicable.

\section{Funding}

The study was funded through departmental sources (grant no. WN757/2019; Nicolaus Copernicus University, Toruń, Poland).

\section{Availability of data and materials}

All data generated or analyzed during this study are included in this published article excluding raw data, which are available from the corresponding author on reasonable request.

\section{Authors' contributions}

EG, MMM, HMN, WH and GG conceived and designed the study. EG, MW and GG performed the experiments. EG, MMM, HMN, MW and GG collected the data. EG, MMM, HMN, IB, MK, AK, WH and GG analyzed the data. All authors read and approved the final version of the manuscript.

\section{Ethics approval and consent to participate}

The study protocol was approved by the Local Ethics Committee for Experiments on Animals, Bydgoszcz, Poland. All studies were performed in accordance with the United States of America National Institutes of Health guidelines.

\section{Patient consent for publication}

Not applicable.

\section{Competing interests}

All authors declare that they have no competing interests.

\section{References}

1. Conlan MJ, Rapley JW and Cobb CM: Biostimulation of wound healing by low-energy laser irradiation a review. J Clin Peridontol 23: 492-496, 1996.

2. Pourzarandian A, Watanabe H, Ruwanpura SM, Aoki A, Noguchi K and Ishikawa I: Er:YAG laser irradiation increases prostaglandin E production via the induction of cyclooxygenase-2 mRNA in human gingival fibroblasts. J Peridontal Res 40: 182-186, 2005.

3. Byrnes KR, Waynant RW, Ilev IK, Wu X, Barna L, Smith K, Heckert R, Gerst H and Anders JJ: Light promotes regeneration and functional recovery and alters the immune response after spinal cord injury. Lasers Surg Med 36: 171-185, 2005.
4. Chow RT, Johnson MI, Lopes-Martins RA and Bjordal JM: Efficacy of low-level laser therapy in the management of neck pain: A systematic review and meta-analysis of randomized placebo or active-treatment controlled trials. Lancet 374: 1897-1908, 2009.

5. Hirakawa S, Fujii S, Kajiya K, Yano K and Dietmar M: Vascular endothelial growth factor promotes sensitivity to ultraviolet B-induced cutaneous photodamage. Blood 105: 2392-2435, 2005.

6. Ribeiro DA and Matsumooto MA: Low-level laser therapy improves bone repair in rats treated with anti-inflammatory drugs. J Oral Rehabil 35: 925-933, 2008.

7. Basford JR: Low intensity laser therapy; Still not an established clinical tool. Lasers Surg Med 16: 331-342, 1995.

8. Tumilty S, Mani R and Baxter GD: Photobiomodulation and eccentric exercise for achilles tendinopathy: A randomized controlled trial. Lasers Med Sci 31: 127-135, 2016.

9. Wu JY, Chen CH, Wang CZ, Ho ML, Yeh ML and Wang YH: Low-power laser irradiation suppresses inflammatory response of human adipose-derived stem cells by modulating intracellular cyclic AMP level and NF-кB activity. PLoS One 8: e54067, 2013.

10. Tuby H, Hertzberg E, Maltz L and Oron U: Long-term safety of low-level laser therapy at different power densities and single or multiple applications to the bone marrow in mice. Photomed Laser Surg 31: 269-273, 2013.

11. Plass CA, Wieselhaler GM, Podesser BK and Prusa AM: Low-level laser irradiation induces photorelaxation in coronary arteries and overcomes vasospasm of internal thoracic arteries. Lasers Surg Med 44: 705-711, 2012.

12. Gal D, Chokshi SK, Mosseri M, Clark RH and Isner JM: Percutaneous delivery of low-level laser energy reverses histamine-induced spasm in atherosclerotic Yucatan microswine. Circulation 82: 756-768, 1992.

13. Steg PG, Rongione AJ, Gal D, Dejesus ST, Clarke RH and Isner JM: Pulsed ultraviolet laser irradiation produces endothelium-independent relaxation of vascular smooth muscle. Circuation 80: 189-197, 1989.

14. Gal D, Steg PG, Rongione AJ, Dejesus ST, Clarke RH and Isner JM: Vascular spasm complicates continuous wave but not pulse laser irradiation. Am Heart J 118: 934-941, 1989.

15. Schwengel RH, Gregory KW, Hearne SE, Scott HJ, Beauman GJ, Mergner WJ, Caplin JL and Ziskind AA: Characterization of pulsed-dye laser-mediated vasodilatation in a rabbit femoral artery model of vasoconstriction. Lasers Surg Med 13: 284-295, 1993.

16. Kipshidze N, Nikolaychik V, Keelan MH, Shankar LR, Khanna A, Kornowski R, Leon M and Moses J: Low-power helium: Neon laser irradiation enhances production of vascular endothelial growth factor and promotes growth of endothelial cells in vitro. Lasers Surg Med 28: 355-364, 2001.

17. Mackiewicz-Milewska M, Grześk E, Kroszczyński AC, Cisowska-Adamiak M, Mackiewicz-Nartowicz H, Baran L, Szymkuć-Bukowska I, Wiciński M, Hagner W and Grześk G: The influence of low level laser irradiation on vascular reactivity. Adv Med Sci 63: 64-67, 2018

18. Grześk G, Mackiewicz-Milewska M, Talar J, Szadujkis-Szadurski L and Bułatowicz I: Rola antagonizmu fizjologicznego angiotensyny II i biostymulacji laserowej w modulowaniu reaktywności mięśniówki gładkiej tętnic. Fizjoter Pol 4: 143-150, 2004.

19. Kling TP, Jim SY and Wittkowski KM: Inflammatory role of two venom components of yellow jackets (Vespula vulgaris): A mast cell degranulating peptide mastoparan and phospholipase a1. Int Arch Allergy Immunol 131: 25-32, 2003.

20. Grześk G, Malinowski B, Grześk E, Wiciński M and Szadujkis-Szadurska K: Direct regulation of vascular smooth muscle contraction by mastoparan-7. Biomed Rep 2: 34-38, 2014.

21. Grześk E, Tejza B, Wiciński M, Malinowski B, Szadujkis-Szadurska K, Baran L, Kowal E and Grześk G: Effect of pertussis toxin on calcium influx in three contraction models. Biomed Rep 2: 584-588, 2014.

22. Grześk E, Darwish N, Stolarek W, Wiciński M, Malinowski B, Burdziński I and Grześk G: Effect of reperfusion on vascular smooth muscle reactivity in three contraction models. Microvasc Res 121: 24-29, 2019.

23. Hajnoczky G, Davies E and Madesh M: Calcium signaling and apoptosis. Biochem Biophys Res Commun 304: 445-454, 2003.

24. Newmeyer DD and Ferguson-Miller S: Mitochondria: Releasing power for life and unleashing the machineries of death. Cell 112: 481-390, 2003. 
25. Grześk G, Wiciński M, Malinowski B, Grześk E, Manysiak S, Odrowąż-Sypniewska G, Darvish N and Bierwagen M: Calcium blockers inhibit cyclosporine A-induced hyperreactivity of vascular smooth muscle cells. Mol Med Rep 5: 1469-1474, 2012.

26. Guide for the Care and Use of Laboratory Animals. NIH Publication No. 85-23. Division of Research Resources, National Institutes of Health, Bethesda, MD, 1985.

27. Van Rossum JM: Cumulative dose-response curves. II. Technique for the making of dose-response curves in isolated organs and the evaluation of drug parameters. Arch Int Pharmacodyn Ther 143: 299-330, 1963.

28. Grześk G and Szadujkis-Szadurski L: Physiological antagonism of angiotensin II and lipopolysaccharides in early endotoxemia: Pharmacometric analysis. Pol J Pharmacol 55: 753-762, 2003.
29. Kanagy NL and Webb RC: Enhanced vascular reactivity to mastoparan, a $\mathrm{G}$ protein activator, in genetically hypertensive rats. Hypertension 23: 946-950, 1994.

30. Birnbaumer L: The discovery of signal transduction by G-proteins. A personal account and an overview of the initial findings and contributions that led to our present understanding. Biochim Biophys Acta 1768: 756-771, 2007.

31. Argiolas A and Pisano JJ: Facilitation of phospholipase $\mathrm{A}_{2}$ activity by mastoparan, a new class of mast cell degranulating peptides from wasp venom. J Biol Chem 258: 13697-13702, 1983.

32. Maegawa Y, Itoh T, Hosokawa T, Yaegashi K and Nishi N: Effects of near-infrared low-level laser irradiation on microcirculation. Lasers Surg Med 27: 427-437, 2000. 